\title{
REVIEW
}

\section{Cancer in relation to occupational exposure to trichloroethylene}

\author{
Noel S Weiss
}

University of

Washington and the

Fred Hutchinson

Cancer Research

Center

N S Weiss

Correspondence to:

Dr N S Weiss, University of

Washington, Box 357236

Seattle, WA 98195, USA.

Accepted 3 September 1995
Trichloroethylene (TCE), $\mathrm{C}_{2} \mathrm{HCl}_{3}$, has been produced commercially for more than 80 years. For the past few decades it has been used primarily for metal degreasing, and as a solvent for oils and resins.

Chronic high dose exposure to TCE increases the incidence of some forms of cancer in some species of rodents. Malignant tumours of the liver occur with increased frequency in Swiss and $\mathrm{B} 6 \mathrm{C} 3 \mathrm{~F}_{1}$ mice of both sexes, after either respiratory ${ }^{1}$ or oral $^{2}$ exposure to TCE, but not in some other strains of mice nor in rats or hamsters. ${ }^{3-6}$ Chronic exposure to TCE increases the incidence of adenocarcinomas of the lung in female ICR and $\mathrm{B} 6 \mathrm{C} 3 \mathrm{~F}_{1}$ mice, ${ }^{17}$ but other strains of mice and rats that have been tested did not develop lung tumours. ${ }^{3}$ Small increases in the occurrence of kidney tubular cell carcinomas and testicular tumours also have occurred after TCE in some (but not all) species of male rats. ${ }^{125}$

The occurrence of cancer has been monitored in several employed groups in whom specific exposure to TCE could be identified. Four of these cohort studies ${ }^{8-11}$ have tabulated the rates of individual types of cancer. The purpose of this article is to review the results of the four cohort studies (augmented, for several of the cancer sites, with data from other studies) to assess the possibility that occupational TCE exposure has an effect on the occurrence of one or more forms of cancer.

\section{Description of the four large cohort studies of workers exposed to TCE}

Table 1 shows the characteristics of the four cohort studies. Investigators at the United States National Cancer Institute identified all civilian employees who had worked for at least one year at an air force base in Utah during 1952-6. ${ }^{8}$ Trichloroethylene was used at the base from the mid-1950s until 1979, and industrial hygiene sampling data indicated potential peak exposures of up to $400 \mathrm{ppm}$ in the mid $1960 \mathrm{~s}$ and $200 \mathrm{ppm}$ in the late $1960 \mathrm{~s}$. However, quantitative assessments of TCE exposure could not be made on individual cohort members, and so a relative index of intensity and duration of TCE exposure was

Table 1 Characteristics of four cohort studies of occurrence of cancer in people occupationally exposed to TCE

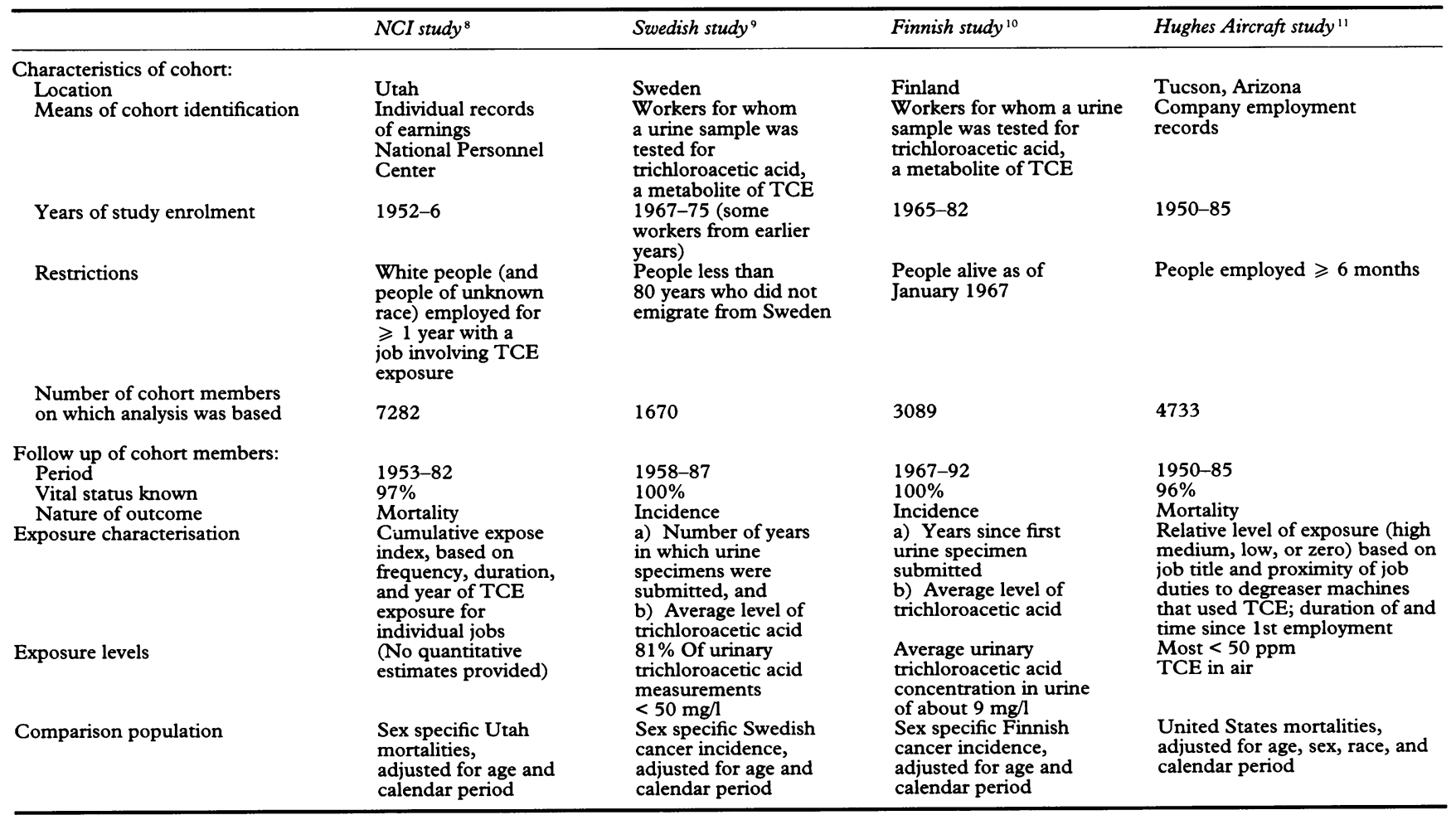


estimated. ${ }^{12}$ About half of the 14457 employees were judged to have been occupationally exposed to TCE. Follow up for mortality (estimated to be $97 \%$ complete) extended from 1953 to the end of 1982 . Death rates in white cohort members of each sex were compared with those for the state of Utah during this period, with adjustment for any differences in age and calendar period of follow up.

Axelson $\mathrm{et}^{\mathrm{al}} \mathrm{l}^{9}$ took advantage of the fact that during 1930-86, only one company in Sweden produced TCE for domestic consumption. That company provided free laboratory analyses of the TCE metabolite, trichloroacetic acid, in urine samples of Swedish subjects who had worked with or near TCE. Records of all people on whom urine tests had been performed from 1967 to 1975 were available, as well as the records of some tested before 1967 . The concentrations of trichloroacetic acid that were found $(81 \%$ of the results were less than $50 \mathrm{mg} / \mathrm{l}$ ) were thought to correspond to an average inhaled exposure of no more than 20 parts per million (ppm). The incidence of cancer among 1670 people so identified was ascertained through the Swedish National Cancer Registry. The cancer incidence in men and women under the age of 80 years was compared with that expected on the basis of Swedish residents as a whole, after adjustment for age and calendar period. (In the publication that presents the findings of this study, ${ }^{9}$ observed and expected numbers of cases of individual sites of cancer are provided only for men, who constituted about $83 \%$ of the cohort). For selected sites of cancer, the presence of any altered risk was assessed in relation to duration of exposure, the mean concentration of the TCE metabolite measured in urine, and by the time since first exposure to TCE.

A study of similar design in Finnish workers was conducted by Anttila et al. ${ }^{10}$ People with known occupational exposure to TCE ( $n=$ 3089) were monitored for urinary concentrations of trichloroacetic acid during 1965-82; on average these concentrations were relatively low (about $9 \mathrm{mg} / \mathrm{l}$ ). The incidence of cancer in the cohort was measured during 1967-92 and compared with rates in Finland during this period. For selected sites of cancer, the standardised incidence ratio was related to the persons' mean urinary concentration of trichloroacetic acid (above and below $16 \mathrm{mg} / \mathrm{l}$, although test results were not available for all cohort members) and to the interval from the first urinary measurement.

The fourth study ${ }^{11}$ was performed in response to the identification of TCE in the wells that supplied water to the Hughes Aircraft plant in Tucson, Arizona. Mortalities among over 20000 employees, and in a subset of 4733 who worked with or around TCE, were monitored during 1958-87. In the subset, a relative index of exposure was estimated for each person based on his or her job title and the proximity to degreaser machines. Only a small fraction of the employees were exposed to estimated TCE concentrations in air of $50 \mathrm{ppm}$ or more. Mortalities (estimated to be $96 \%$ complete) from individual types of cancer, specific for duration of employment and time since first employment, were compared with United States population rates, adjusted for age, sex, race, and calendar period.

In this review, the cohort mortality study of aircraft manufacturing workers in southern California conducted by Garabrant et al ${ }^{13}$ was considered in only an ancillary way. Although TCE was present in the plant where these people had been employed, a detailed review of the job duties of a sample of the cohort, along with the manufacturing processes and materials used at the plant, indicated that only $37 \%$ of the jobs there involved TCE exposure. No cancer mortalities were provided for these people alone.

\section{Findings}

In the United States National Cancer Institute study there were 281 cancer deaths in people judged to have been exposed to TCE, about $12 \%$ below the number expected. The 125 cancer deaths in the Hughes Aircraft study were $22 \%$ fewer than expected. In the Swedish male workers, 107 cases of cancer occurred, about the same as expected. The 22 cancer cases in the Swedish female workers were $32 \%$ greater than expected, but the $95 \%$ confidence interval (95\% CI) around this estimate was quite wide $(-15 \%$ to $+99 \%)$. In the Finnish cohort there were 208 cases of cancer diagnosed, about $5 \%$ more than expected.

\section{CANCER OF THE GASTROINTESTINAL TRACT} (TABLE 2)

In neither the National Cancer Institute nor the Hughes Aircraft study was there an indication

Table 2 Occurrence of cancer of the gastrointestinal tract in the four cohort studies

\begin{tabular}{|c|c|c|c|c|c|c|c|c|c|c|c|c|c|c|c|c|c|c|c|c|c|}
\hline \multirow[b]{4}{*}{ Site of cancer } & \multicolumn{12}{|c|}{ NCI study } & \multirow{3}{*}{\multicolumn{3}{|c|}{ Swedish study }} & \multirow{3}{*}{\multicolumn{3}{|c|}{ Finnish study }} & \multirow{3}{*}{\multicolumn{3}{|c|}{$\begin{array}{l}\text { Hughes Aircraft } \\
\text { study }\end{array}$}} \\
\hline & & & & Cur & ulativ & exposu & re in & & & & & & & & & & & & & & \\
\hline & \multicolumn{3}{|c|}{ All employees } & \multicolumn{3}{|c|}{$<5$} & \multicolumn{3}{|c|}{$5-25$} & \multicolumn{3}{|c|}{$>25$} & & & & & & & & & \\
\hline & $O$ & $E$ & $S M R$ & $O$ & $E$ & $S M R$ & $O$ & $E$ & $S M R$ & $O$ & $E$ & $S M R$ & $O$ & $E$ & SIR & $O$ & $E$ & $S I R$ & $O$ & $E$ & $S M R$ \\
\hline $\begin{array}{l}\text { Buccal cavity } \\
\text { and pharynx }\end{array}$ & & 6.3 & 0.8 & 2 & & & & & & & & & & & & & & & & & \\
\hline Oesophagus & 6 & 5.9 & 1.0 & 2 & $2 \cdot 4$ & 0.8 & - & $1 \cdot 4$ & $\underline{0}$ & 3 & $2 \cdot 5$ & $\underline{1 \cdot 2}$ & - & - & E & - & - & - & $\begin{array}{l}1 \\
2\end{array}$ & $\begin{array}{l}4 \cdot 4 \\
4 \cdot 0\end{array}$ & $\begin{array}{l}0 \cdot 2 \\
0 \cdot 5\end{array}$ \\
\hline Stomach & 14 & $18 \cdot 0$ & 0.8 & - & - & - & - & - & - & - & - & - & 5 & $\overline{7 \cdot 2}$ & $\overline{0.7}$ & $\overline{17}$ & $\overline{13} \cdot 3$ & $1 \cdot 28$ & 2 & $\begin{array}{l}4.0 \\
6.9\end{array}$ & $\begin{array}{l}0.3 \\
0.1\end{array}$ \\
\hline Colon & 29 & $28 \cdot 8$ & $1 \cdot 0$ & - & - & - & - & - & - & - & - & - & 8 & $7 \cdot 8$ & $1 \cdot 0$ & 8 & 9.5 & 0.8 & 14 & $14 \cdot 0$ & 1.0 \\
\hline Rectum & 5 & $7 \cdot 4$ & $0 \cdot 7$ & - & - & - & - & - & - & - & - & - & - & - & - & 12 & $7 \cdot 0$ & 1.7 & 4 & $4 \cdot 0$ & i. 0 \\
\hline Biliary passages & 8 & $3 \cdot 6$ & $2 \cdot 2$ & 3 & $1 \cdot 2$ & $2 \cdot 5$ & 3 & $0 \cdot 7$ & $4 \cdot 3$ & 2 & $1 \cdot 6$ & $1 \cdot 3$ & - & - & - & 4 & $2 \cdot 6$ & $1 \cdot 6$ & - & - & - \\
\hline Liver & 2 & 1.8 & $1 \cdot 1$ & 2 & $0 \cdot 6$ & $3 \cdot 2$ & 0 & $0 \cdot 4$ & 0 & 0 & 0.7 & 0 & 4 & $2 \cdot 8$ & $1 \cdot 4$ & 5 & $2 \cdot 2$ & $2 \cdot 3$ & 5 & $2 \cdot 7$ & $1 \cdot 8$ \\
\hline Pancreas & 16 & $19 \cdot 4$ & $0 \cdot 8$ & 6 & $7 \cdot 2$ & $0 \cdot 8$ & 3 & $4 \cdot 3$ & $0 \cdot 7$ & 7 & $7 \cdot 8$ & 0.9 & 1 & $4 \cdot 1$ & 0.2 & 11 & $6 \cdot \overline{8}$ & 1.6 & 3 & $8 \cdot 3$ & $0 \cdot 4$ \\
\hline
\end{tabular}

NCI = National Cancer Institute; $\mathrm{O}=$ observed; $\mathrm{E}=$ expected; SMR = standardised mortality ratio; SIR = standardised incidence ratio. 
Table 3 Occurrence of lymphatic and haematopoetic cancers in the four cohort studies

\begin{tabular}{|c|c|c|c|c|c|c|c|c|c|c|c|c|c|c|c|c|c|c|c|c|c|}
\hline \multirow[b]{4}{*}{ Site of cancer } & \multicolumn{12}{|c|}{ NCI study } & & & & & & & & & \\
\hline & \multirow{2}{*}{\multicolumn{3}{|c|}{ All employees }} & \multicolumn{9}{|c|}{ Cumulative exposure index } & & & & & & & \multirow{2}{*}{\multicolumn{3}{|c|}{$\begin{array}{l}\text { Hughes Aircraft } \\
\text { study }\end{array}$}} \\
\hline & & & & \multicolumn{3}{|c|}{$<5$} & \multicolumn{3}{|c|}{$5-25$} & \multicolumn{3}{|c|}{$>25$} & \multicolumn{3}{|c|}{ Swedish study } & \multicolumn{3}{|c|}{ Finnish study } & & & \\
\hline & $O$ & $E$ & $S M R$ & $O$ & $E$ & $S M R$ & $O$ & $E$ & $S M R$ & $O$ & $E$ & $S M R$ & $O$ & $E$ & SIR & $O$ & $E$ & SIR & $O$ & $E$ & $S M R$ \\
\hline \multirow{4}{*}{$\begin{array}{l}\text { Hodgkin's disease } \\
\text { Leukaemia } \\
\text { Multiple myeloma } \\
\text { Non-Hodgkin's } \\
\quad \text { lymphoma }\end{array}$} & 4 & $4 \cdot 6$ & 0.9 & - & - & - & - & - & - & 一 & - & - & 1 & 0.9 & $1 \cdot 1$ & 3 & $1 \cdot 8$ & $1 \cdot 7$ & 0 & $1 \cdot 3$ & 0 \\
\hline & 11 & $15 \cdot 0$ & 0.7 & 4 & $5 \cdot 6$ & 0.7 & 0 & 3.5 & 0 & 7 & $6 \cdot 0$ & $1 \cdot 2$ & - & - & - & 5 & $4 \cdot 6$ & $1 \cdot 1$ & 2 & $5 \cdot 4$ & 0.4 \\
\hline & 6 & $5 \cdot 3$ & $1 \cdot 1$ & 3 & $2 \cdot 0$ & 1.5 & 1 & $1 \cdot 2$ & 0.8 & 2 & $2 \cdot 2$ & 0.9 & 1 & $1 \cdot 8$ & 0.6 & 4 & $2 \cdot 5$ & $1 \cdot 6$ & - & - & - \\
\hline & 14 & $11 \cdot 2$ & $1 \cdot 3$ & 6 & $4 \cdot 2$ & $1 \cdot 4$ & 3 & $2 \cdot 5$ & $1 \cdot 2$ & 5 & $4 \cdot 4$ & $1 \cdot 1$ & 5 & $3 \cdot 2$ & $1 \cdot 6$ & 8 & $4 \cdot 4$ & $1 \cdot 8$ & 6 & $6 \cdot 8$ & 0.9 \\
\hline
\end{tabular}

Abbreviations as for table 2 .

of an increased mortality from cancers of the oral cavity or oesophagus. (No data for these sites were presented in the Nordic studies.) In all four studies, rates of cancers of the stomach, colon, rectum, and pancreas were similar to those of the population as a whole. In an interview based case-control study of colon cancer among residents of the Umea area (Sweden) during $1980-3,{ }^{14}$ a history of occupational exposure to TCE was associated with a $1 \cdot 5$-fold increase in risk, based on a small number of exposed people $(95 \% \mathrm{CI}=0.4$ to $5 \cdot 7)$. A stronger association was seen in the still smaller group of people exposed to TCE as dry cleaners (odds ratio $(\mathrm{OR})=7 \cdot 4,95 \% \mathrm{CI}=1 \cdot 1$ to 47.0). The basis for the divergent findings of this and the Swedish cohort study ${ }^{9}$ is not known.

Occurrence of liver cancer was increased, at least to a small extent, in each of the cohort studies. Adding the four together (with the experience only of the occupationally exposed subset of the Hughes Aircraft cohort) there were 16 cases (expected $=9 \cdot 5$ ). In the National Cancer Institute study, the two deaths from liver cancer occurred in those employees with the lowest category of estimated cumulative exposure. In the Hughes Aircraft study, an increased risk of liver cancer was present in people with less than 10 years employment (three cases, SMR $=1.8$ ) and 20 or more years employment (two cases, SMR $=4 \cdot 3$ ), but no deaths occurred in the people who had worked for 10-19 years (expected $=0 \cdot 6$ ). Of the four people in the Swedish cohort who developed liver cancer, three had worked with TCE for two or more years, but each of the three were in the lowest category of concentrations of urinary trichloroacetic acid. In the Finnish study, three of the five cases occurred more than 20 years after the first urinary measurement was obtained (SIR $=6 \cdot 1)$, and two occurred among people whose mean trichloroacetic acid concentrations in urine were greater than
$16 \mathrm{mg} / 1$ (SIR $=2 \cdot 7)$. No cases of liver cancer were identified during 1951-77 among people involved in the manufacturing of TCE at a British plant, ${ }^{15}$ but only 0.3 would have been expected based on incidences in the population in which the plant was located. Case-control studies of liver cancer conducted in both Sweden ${ }^{16}$ and Finland ${ }^{17}$ have obtained information through interviews on occupational exposure to organic solvents. Very few people in these studies cited exposure specifically to TCE, and it is possible that they already are represented in the two cohort studies of workers exposed to TCE from those countries.

Mortality from biliary tract cancers occurred twice as often as expected in the National Cancer Institute study. This increased rate was, however, based on only eight deaths, and there was no suggestion that the size of the increased risk rose with increasing cumulative exposure (table 2). In the Finnish study a $60 \%$ increased risk (based on four cases) was observed for biliary tract cancers. No results for these tumours were presented in the other two studies.

\section{LYMPHATIC AND HAEMATOPOETIC CANCERS \\ (TABLE 3)}

In none of the cohort studies was there any suggestion of an increased risk of Hodgkin's disease or leukaemia associated with occupational exposure to TCE. The occurrence of nonHodgkin's lymphoma was slightly increased in the National Cancer Institute and Swedish cohorts, and increased by a factor of two in the Finnish study. There was no corresponding increase among Hughes Aircraft employees who had worked with or around TCE, nor among the southern California aircraft workers. ${ }^{13}$ In neither the National Cancer Institute, the Swedish, nor the Finnish study did the modest excess of occurrence of non-Hodgkin's lymphoma increase with increasing exposure to TCE.

A case-control study of people with non-

Table 4 Occurrence of cancers of the urinary tract in the four cohort studies

\begin{tabular}{|c|c|c|c|c|c|c|c|c|c|c|c|c|c|c|c|c|c|c|c|c|c|}
\hline \multirow[b]{4}{*}{ Site of cancer } & \multicolumn{12}{|c|}{ NCI study } & \multirow{3}{*}{\multicolumn{3}{|c|}{ Swedish study }} & \multirow{3}{*}{\multicolumn{3}{|c|}{ Finnish study }} & \multirow{3}{*}{\multicolumn{3}{|c|}{$\begin{array}{l}\text { Hughes Aircraft } \\
\text { study }\end{array}$}} \\
\hline & & & & $\mathrm{Cun}$ & ulative & exposu & re ind & & & & & & & & & & & & & & \\
\hline & \multicolumn{3}{|c|}{ All employees } & \multicolumn{3}{|c|}{$<5$} & \multicolumn{3}{|c|}{$5-25$} & \multicolumn{3}{|c|}{$>25$} & & & & & & & & & \\
\hline & $O$ & $E$ & $S M R$ & $O$ & $E$ & $S M R$ & $O$ & $E$ & $S M R$ & $O$ & $E$ & $S M R$ & $O$ & $E$ & $S I R$ & $O$ & $E$ & $S I R$ & $O$ & $E$ & $S M R$ \\
\hline $\begin{array}{l}\text { Kidney } \\
\text { Bladder }\end{array}$ & $\begin{array}{r}8 \\
11\end{array}$ & $\begin{array}{l}7.5 \\
7.9\end{array}$ & $\begin{array}{l}1 \cdot 1 \\
1 \cdot 4\end{array}$ & $\begin{array}{l}5 \\
4\end{array}$ & $\begin{array}{l}2 \cdot 8 \\
2 \cdot 9\end{array}$ & $\begin{array}{l}1.8 \\
1.4\end{array}$ & $\begin{array}{l}0 \\
3\end{array}$ & $\begin{array}{l}1 \cdot 7 \\
1 \cdot 8\end{array}$ & $\begin{array}{l}0 \\
1.7\end{array}$ & $\begin{array}{l}3 \\
4\end{array}$ & $\begin{array}{l}2 \cdot 9 \\
3 \cdot 2\end{array}$ & $\begin{array}{l}1.0 \\
1.3\end{array}$ & $\begin{array}{l}6 \\
8\end{array}$ & $\begin{array}{l}5 \cdot 2 \\
7.9\end{array}$ & $\begin{array}{l}1 \cdot 2 \\
1.0\end{array}$ & 5 & $\begin{array}{l}6.9 \\
6 \cdot 1\end{array}$ & $\begin{array}{l}0.9 \\
0.8\end{array}$ & $\begin{array}{l}3 \\
3\end{array}$ & $\begin{array}{l}3 \cdot 3 \\
3.5\end{array}$ & $\begin{array}{l}0.9 \\
0.9\end{array}$ \\
\hline
\end{tabular}

Abbreviations as for table 2 . 
Table 5 Occurrence of other cancers in the four cohort studies

\begin{tabular}{|c|c|c|c|c|c|c|c|c|c|c|c|c|c|c|c|c|c|c|c|c|c|}
\hline \multirow[b]{4}{*}{ Site of cancer } & \multicolumn{12}{|c|}{ NCI study } & \multirow{3}{*}{\multicolumn{3}{|c|}{ Swedish study }} & \multirow{3}{*}{\multicolumn{3}{|c|}{ Finnish study }} & \multirow{3}{*}{\multicolumn{3}{|c|}{$\begin{array}{l}\text { Hughes Aircraft } \\
\text { study }\end{array}$}} \\
\hline & & & & Cun & ulative & exposu & e ind & & & & & & & & & & & & & & \\
\hline & \multicolumn{3}{|c|}{ All employees } & \multicolumn{3}{|c|}{$<5$} & \multicolumn{3}{|c|}{$5-25$} & \multicolumn{3}{|c|}{$>25$} & & & & & & & & & \\
\hline & $O$ & $E$ & $S M R$ & $O$ & $E$ & $S M R$ & $O$ & $E$ & $S M R$ & $O$ & $E$ & $S M R$ & $O$ & $E$ & $S I R$ & $O$ & $E$ & $S I R$ & $O$ & $E$ & $S M R$ \\
\hline Lung & 64 & $67 \cdot 9$ & 0.9 & 25 & $26 \cdot 7$ & 0.9 & 14 & $16 \cdot 3$ & 0.9 & 25 & $25 \cdot 0$ & $1 \cdot 0$ & 9 & $13 \cdot 2$ & $0 \cdot 7$ & 25 & $27 \cdot 2$ & 0.9 & 41 & $44 \cdot 6$ & 0.9 \\
\hline Breast & 9 & 11.5 & $0 \cdot 8$ & 3 & $2 \cdot 8$ & $1 \cdot 1$ & 2 & 1.7 & $1 \cdot 2$ & 4 & $7 \cdot 0$ & 0.6 & - & - & - & $\underline{-}$ & - & - & 8 & $11 \cdot 3$ & $0 \cdot 7$ \\
\hline Prostate & 22 & $27 \cdot 6$ & 0.8 & 7 & $10 \cdot 3$ & 0.7 & 3 & $6 \cdot 2$ & 0.5 & 12 & $11 \cdot 1$ & $1 \cdot 1$ & 26 & $20 \cdot 7$ & $1 \cdot 3$ & 13 & $9 \cdot 4$ & 1.4 & 12 & $8 \cdot 6$ & $1 \cdot 4$ \\
\hline Central nervous system & 9 & 11.5 & $0 \cdot 8$ & 3 & $4 \cdot 5$ & 0.7 & 4 & $2 \cdot 7$ & $1 \cdot 5$ & 2 & $4 \cdot 3$ & 0.5 & - & - & - & 9 & $8 \cdot 3$ & $1 \cdot 1$ & 1 & $4 \cdot 1$ & $0 \cdot 2$ \\
\hline
\end{tabular}

Abbreviations as for table 2 .

Hodgkin's lymphoma $(\mathrm{n}=109)$ and Hodgkin's disease $(n=60)$ combined, sought information through interviews about exposure to organic solvents. ${ }^{18}$ Continuous TCE exposure for at least one week, or intermittent exposure totalling at least one month, was reported by seven of the cases compared with only three of 338 controls (crude ORs $=4 \cdot 8$ ). Although the results of this study support the hypothesis that exposure to TCE is associated with either or both of non-Hodgkin's lymphoma and Hodgkin's disease, the potential for differential reporting of exposure between cases and controls-especially given that for $37 \%$ of subjects the data were obtained from a surrogate respondent-argues for caution when interpreting the results.

CANCERS OF THE URINARY TRACT (TABLE 4) In the National Cancer Institute cohort only, deaths from bladder cancer were somewhat more common than expected (SMR-1.4), but there was no indication of a particularly high rate in people most heavily exposed to TCE. Cancers of the kidney were as common in each of the four cohorts exposed to TCE as in the general population.

In a fifth cohort, consisting of 169 male employees exposed to TCE in a German cardboard factory in which the incidence of only renal cancer was described, ${ }^{19}$ a different result was obtained. During a follow up period averaging 34 years, five cases of kidney cancer occurred, compared with no cases in 190 nonexposed workers, and an expected incidence (based on population rates) of approximately $0 \cdot 6$. Although no measurements of TCE concentrations were made at this factory, a description of the ways in which TCE was used there, along with anecdotal reports of the frequency of acute symptoms of TCE toxicity, suggest that the exposure of these workers was relatively high compared with that of the other cohorts studied. Although the increased incidence of kidney cancer that was seen could be indicative of an adverse effect of very high occupational exposure to TCE - especially given that mutagenic metabolites of TCE may be preferentially formed in renal tubular cells ${ }^{19}$-this finding should be interpreted cautiously. Abdominal sonography was performed on all study participants (exposed and non-exposed), suggesting that the identification of a suspected altered risk of renal cancer in the plant-perhaps on the basis of a recognised cluster of cases among members of this workforce-had occurred before the start of the study. Thus, the meaning of these results will not be clear until a study has been conducted among employees of one or more other factories that had similar exposure conditions.

\section{OTHER CANCERS (TABLE 5)}

Occurrence of lung cancer was no more common in members of the four cohorts than in the population at large. Similar findings ${ }^{20}$ were obtained in a study of people employed in a manufacturing plant in northern Illinois that had used TCE as a degreasing agent. During 1957-83, nine deaths from lung cancer occurred, in contrast to $12 \cdot 1$ expected. In none of the studies was there an increase in the occurrence of tumours of the breast or central nervous system. A case-control study of astrocytic brain tumours ${ }^{21}$ also found no association with employment that potentially involved exposure to TCE. Occurrence of prostate cancer was increased to a small degree in all but the National Cancer Institute study. In the Finnish study, although the excess incidence of prostate cancer was confined to the period after 20 years from the time of the first measurement of trichloroacetic acid, it was also confined to the men in the lower exposure category.

\section{Discussion}

Data from the epidemiological studies completed to date suggest that, with the possible exceptions of cancers of the liver, nonHodgkin's lymphoma, biliary tract, and kidney, no type of cancer seems to develop more commonly in people occupationally exposed to TCE than in members of the population at large.

Rates of liver cancer were increased, but in all four cohort studies only a total of 16 cases were identified, and the size of the increase was modest and failed to grow with increasing estimated exposure to TCE. Despite the ability of TCE to produce liver cancer in several mouse strains, the absence of a clear increase in the risk of this disease associated with occupational exposure to TCE has a possible explanation. Among experimental animals, the development of liver cancer correlates closely with concentrations of the metabolite trichloroacetic acid produced after TCE exposure (high in mice, low in rats (and in humans)), and with the ability of trichloroacetic acid to stimulate the production of peroxisomes (a cellular organelle). The presence of peroxisomes seems to be a link between trichloroacetic acid and the development of liver cancer in mice, ${ }^{22}$ but peroxisomes 
are not induced by trichloroacetic acid in humans. ${ }^{23}$

Only the National Cancer Institute and Finnish studies reported on the occurrence of cancers of the biliary tract. The failure of the other two studies to provide corresponding data could well be due to the absence of any observed cases, or the absence of any association with this site based on but one or two cases. This, in conjunction with the lack of a graded increase in risk of biliary tumours with increasing cumulative exposure in the National Cancer Institute study argues for caution when trying to interpret these results.

Rates of lung cancer among cohort members exposed to TCE were very close to those expected. An explanation for the lack of relation of lung cancer to exposure to TCE in humans, in contrast to a positive finding in two strains of mice, may lie in differences in the prevalence and nature of Clara cells across species. Clara cells are unusually common in the respiratory tract of mice, and they metabolise TCE primarily to chloral, ${ }^{24}$ a genotoxic substance. In humans (and in rats, who also do not develop lung tumours in response to TCE), Clara cells are far less numerous than in mice, and human Clara cells seem to lack the metabolic capacity to produce chloral. 2425

Each of the four principal cohort studies measured or estimated the degree of exposure to TCE, at least in qualitative terms. Therefore, they were able to exclude from some analyses the mortality experience of people with little or no contact with TCE. In the three studies that sought to estimate absolute concentrations of exposure (all but the National Cancer Institute study), those concentrations generally were found to be low, within current recommendations for a threshold limit value of $50 \mathrm{ppm} \mathrm{rec-}$ ommended by the American Conference of Governmental Industrial Hygienists. ${ }^{26}$ It is unclear to what extent the results obtained to date would pertain to more heavily exposed people.

In February of 1995, a working group of the International Agency for Research on Cancer (IARC) concluded that there was limited evidence from studies in humans that TCE exposure could cause cancer-that is,

"a positive association has been observed between exposure to the agent ... and cancer for which a causal relationship is . . credible, but chance, bias or confounding could not be ruled out with reasonable confidence". ${ }^{27}$

This conclusion was based primarily on the results for cancers of the liver and biliary tract and for non-Hodgkin's lymphoma. (Given the IARC guidelines for combining results from epidemiological studies with positive results in experimental animals, a judgment of limited evidence produced an overall evaluation of TCE exposure as being probably carcinogenic to humans.) It is clear from a review of the data that, both in terms of the small relative increases seen and the small number of observations upon which those increases are based, the evidence currently available in support of a causal hypothesis is quite limited. Continued follow up of existing cohorts of people occupationally exposed to TCE, and the assembly of new cohorts, is very much in order.

This work was supported by the Halogenated Solvents Industry Alliance.

1 Maltoni C, Lefemine G, Cotti G, Perino G. Long-term carcinogenicity bioassays on trichlorethylene administered by inhalation to Sprague-Dawley rats and Swiss and $\mathrm{B} 6 \mathrm{C} 3 \mathrm{~F}_{1}$ mice. Ann NYAcad Sci 1988;534:316-42.

2 US NTP (National Toxicology Programme). Carcinogenesis bioassay of trichloroethylene in Fischer-344/N rats and B6C3F1 mice. Research Triangle Park, NC: NTP, 1983.

3 Henschler D, Romen W, Elsasser HM, Reichert D, Eder E, Radwan Z. Carcinogenicity study of trichloroethylene by long-term inhalation in three animal species. Arch Toxicol long-term inhalation

4 Henschler D, Romen W, Eder E. Carcinogenicity study of trichloroethylene with and without epoxide stabilizers in mice. F Cancer Res Clin Oncol 1984;104:149-56.

5 US NTP (National Toxicology Programme). NTP technical report on the toxicology and carcinogenesis studies of trichloroethylene in four strains of rats. TR 273. Research Triangle Park, NC: NTP, 1988.

6 Herren-Freund SL, Pereira MA, Khoury MD, Olson G. The carcinogenicity of trichloroethylene and its metabolites, trichloroacetic acid and dichloroacetic acid, in mouse liver. Toxicol Appl Pharmacol 1987;90:183-9.

7 Fukuda K, Takemoto K, Tsurata $\mathrm{H}$. Inhalation carcinogenicity of trichlorethylene in mice and rats. Ind Health 1993;21:243-54.

8 Spirtas R, Stewart P, Lee S. Retrospective cohort mortality study of workers at an aircraft maintenance facility II.
Exposures and the assessment. Br $\mathcal{I}$ Ind Med 1991;48: Exposu.

9 Axelson O, Selden A, Andersson K, Hogstedt C. Updated and expanded Swedish cohort study of trichloroethylene and cancer risk. F Occup Med 1994;36:556-62.

10 Anttila A, Pukkala E, Sallmen M, Hernberg S, Hemminki K. Cancer incidence among Finnish workers exposed to halogenated hydrocarbons. $\mathcal{F}$ Occup Med 1995;37:797-806.

11 Wong O, Morgan R. Final report: historical prospective mortality study of Hughes Aircraft employees at air force plant No 44. ity study of Hughes Aircraft employees at air force

12 Stewart PA, Lee JS, Marano DE, Spirtas R, Forbes CD, Blair A. Retrospective cohort mortality study of workers at alair A. Retrospective cohort mortality study of workers at an aircraft maintenance facility II. Expos

13 Garabrant DH, Held J, Langhold B, Bernstein L. Mortality of aircraft manufacturing workers in southern California. $\mathrm{Am}$ f Ind Med 1988;13:683-93.

14 Fredriksson M, Bengtsson N-O, Hardell L, Axelson $O$. Colon cancer, physical activity, and occupational exposures, a case-control study. Cancer 1989;63:1838-42.

15 Paddle GM. Incidence of liver cancer and trichloroethylene manufacture: joint study by industry and a cancer registry. $B M \Im$ 1983;286:846.

16 Hardell L, Bengtsson NO, Jonsson U, Eriksson S, Larsson LG. Aetiological aspects on primary liver cancer with special regard to alcohol, organic solvents and acute intermittent porphyria-an epidemiological investigation. $\mathrm{Br} f$ tent porphyria-an ep

17 Hernberg S, Kauppinen T, Riala R, Korkala ML, Asikainen $\mathrm{U}$. Increased risk for primary liver cancer among women exposed to solvents. Scand $\mathcal{f}$ Work Environ Health 1988;14:356-65.

18 Hardell L, Eriksson M, Lenner P, Lundgren E. Malignant lymphoma and exposure to chemicals, especially organic solvents, chlorophenols and phenoxy acids: a case-control study. Br f Cancer 1981;43:169-76.

19 Henschler D, Vamvakas S, Lammert M, Dekant W, Kraus $\mathrm{B}$, Thomas $\mathrm{B}$, et al. Increased incidence of renal cell tumors in a cohort of cardboard workers exposed to trichloroethene. Arch Toxicol 1995;69:291-9.

20 Shindell S, Ulrich S. A cohort study of employees of a manufacturing plant using trichloroethylene. F Occup Med ufacturing plant

21 Heineman EF, Cocco P, Gomez MR, Dosemeci M, Stewart $\mathrm{PA}$, Haynes RB, et al. Occupational exposure to chlorinated aliphatic hydrocarbons and risk of astrocytic brain cancer. Am F Ind Med 1994;26:155-69.

22 Ashby J, Brady A, Elcombe CR, Elliott BM, Ishmael J, Odum J, et al. Mechanistically-based human hazard assessment of peroxisome proliferator-induced hepatocarcinogenesis. Hum Exp Toxicol 1994;13(suppl 2).

23 Elcombe CR. Species differences in carcinogenicity and peroxisome proliferation due to trichloroethylene. A biochemical human hazard assessment. Arch Toxicol 1985; 8(suppl):6-17.

24 Odum J, Foster JR, Green T. A mechanism for the development of Clara cell lesions in the mouse lung after exposure to trichloroethylene. Chem Biol Interact 1992;83:135-53.

25 Smith MN, Greenberg DS, Spjut HJ. The Clara cell: a complete ultrastructural study in mammals. Am $\mathcal{f}$ Anat 1979; plete ultrastrin

26 American Conference of Governmental Industrial Hygienists. Threshold limit values for chemical substances and Hygienists. Threshold limit values for chemical substances and physical agents and biological

27 International Agency for Research on Cancer. IARC monographs on the evaluation of carcinogenic risks to humans: preamble. Vol 62. Wood dust and formaldehyde. Geneva: IARC World Health Organization, 1995. 